\title{
English Used by Sellers on Campuhan Street, Ubud
}

\author{
Desak Made Icha Agustina ${ }^{1}$, A. A Gede Suarjaya ${ }^{2 *}$, I Kadek Agus Darmawan ${ }^{3}$ \\ Universitas Warmadewa Denpasar-Bali, Indonesia ${ }^{123}$ \\ \{gedesuarjaya@gmail.com² ${ }^{2}$,oswaldus.wegu@gmail.com ${ }^{3}$ \}
}

\begin{abstract}
This paper aimed to analyse about the English function and expression that uttered by sellers in five art shops for tourist. The sellers are used as the respondents of data sources are examined are is five persons. Those respondents are one man and four woman. Observing, interviewing and by recording or taking note are the methods of collecting the data. Then result of the research is presented as discussion engagingly by dissecting dependent on the theory applied. The Theory which is utilized to investigate the information is the theory language work which is mostly taken from Blundell (1982). Beside this theory, the theory of Leo Jones (1986) is used as supporting theory. Based on the data analysis, it can be conclude that in communicating with the tourist, the sellers at Campuhan, Ubud as participants need to utilize a few elements of English Expressions. The English expression which they have imparted to the traveler are the expression for the capacity of : (1) greeting (2) giving price (3) getting information (4) inviting someone, (5) offering things, and (6) thanking. The vast majority of the English expression utilized in their correspondence by the sellers to the tourists are informal and neutral communicated. As conclusion, most of sellers made ungrammatical language to convey the expression, but their purpose can be understood by the tourists when they serve the tourists in a friendly.
\end{abstract}

Keywords: English language; expression;function of english

\section{Introduction}

People communicate with each other in their lives. They share a feeling and thought from one and others. In communication, people also need channels of information. Communication is sending and receiving information between two or more people. Criticism permits the sender to decide if the message has been gotten and perceived. ${ }^{[1]}$. In communication, we use language; language is an arrangement of communication which comprises a lot of sounds and composed images which are utilized by people ${ }^{[2]}$. One of the most popular languages in the world is the English language. They study English not just to build up their careers but also to get more knowledge and to improve their skill in communication. The tourism industry is one of many sectors that use English as the primary language. In Indonesia, the development of the tourism industry has increased rapidly.

Bali is one of the best tourism destinations in Indonesia and can also be considered one of the most famous tourism place in the entire world. As the main of the tourism industry in 
Indonesia, one of destination in Bali is Ubud. Ubud is famous for relaxation and their yoga life. In the area of Campuhan Ubud, there is the one best place to do yoga or meditation. On the Campuhan Street, there are many activities transactions, such as art shop, restaurants, and taxi service. In the Campuhan Street English is very important in communicate.

This is the reason why the sellers need to learn English because they usually communicate with the tourist. Most of the sellers do not know appropriate expressions in English due to there are many expressions in English. Fortunately greeting, inviting someone, offering things, giving price, getting information, giving information, giving suggestion, requesting, apologizing, saying good bye, and thanking are some expressions related to the English function commonly used by sellers ${ }^{[3]}$. It is important for sellers to learn about English as the medium of communication with their guests.

The latest related research are used to support as well as distinguish the research with this present research. The first research was study about language functions used by taxi drivers in Sanur beach, the expressions used by them were expression for the function of greeting, offering something, requesting, apologizing, and thanking ${ }^{[4]}$. This present study tries to reveal the expression used by seller. The second related research was telling about language function and expression used by guidance tour at Bali Best Memory Tours in Handling Tourist. The results of the research showed that there were 6 language capacities discovered found such as function for greeting, function for giving information, function for offering something, function for thanking, function for apologizing and function for saying goodbye ${ }^{[5]}$.

Based on the description of the background above, the researcher is interested in investigating the English used by sellers on Campuhan Street Ubud. Talking about English expressions, there are very wide and it can be analyzed from various aspects. Therefore, the topic of discussions is limited to achieving more specific problems into what language functions are commonly used by sellers at Campuhan Ubud? And what expressions are shown by each functions found in every conversation spoken by the sellers at Campuhan Ubud? Thus, the aim of this research is to understand about language functions which are commonly used by sellers at Campuhan Street, Ubud.

\section{Methods}

In this research, English used by sellers at Campuhan, Street Ubud was applied as the data source. In this case, the data source was taken from the conversations between sellers and their tourist at Campuhan. Therefore, the focus of the data of the research is lied on English function used by sellers on Campuhan, Ubud. Observing, interviewing and by recording or taking note are the methods of collecting the data. The conversation between sellers and tourists and were listened carefully by the writer and it is recorded with the phone. The sellers were also interviewed if the data weren't clear enough. After all the data were collected, the data analyzed and identified where each expression is analyzed by based on function of the theory in English suggest by Blundell. Then, made of expressions also is presented as discussion engagingly by breaking down dependent on the hypothesis applied. The instances of discussion are investigated methodicallly by recognizing and looking at expression used to communicate by resellers on Campuhan, Ubud. 


\section{Result and Discussion}

After collecting and grouping the data based on their functions, it can be found that there were several English functions and their expressions produced by sellers in Campuhan Ubud. Those English functions are: greeting, giving price, getting information, inviting someone, offering things, thanking.

\subsection{Greeting}

The expressed greeting are utilized by the speakers to build up contact with the others, for instance with their companions, weird individuals, or others. This expression was utilized by them to begin their conversation with the tourists to sell things or art works to the tourist.

Desi : Good morning. How are you?

Tourist : : Good morning, I'm fine. Thank you.

Desi : Have looks please.

Tourist : How much is it?

The data above is a greeting function between seller and tourist. It is categorized as mean that the seller greets the tourist. The sellers used this utterance when the tourist was walking in front of their shop. This expression functionally to usual expression because it is expressed with word "good".

Ernawati : Hallo, Sir.

Tourist : Hallo, how are you?

Ernawati : Good, nice sarong, please!

From the data 2 above, the bold words "hallo, Sir." shows that the seller used a greeting function. It is categorized function as starting the conversation when the people are speaking with each other. Seen from the word utilized, this expression has a place with formal expression since she utilized a conventional welcome "Hello" and followed by "sir" word to welcome the tourists in an affable way.

Oka : Hi, Have looks please.

Tourist : Hallo. What is the price of this dress?

Oka : One hundred thousand rupiah.

The sentence in bold in data 3 above is considered on greeting function. This is categorized seller wants to give their own instructions and attitudes to make connections to tourist in initiating communication. This greeting is informal expression. It is called an informal expression because of sellers greeted tourist by said "hi" that word as the opening of this conversation, and followed by "have looks please." as the closing of this expression.

Sarinata : Hello, Good morning.

Tourist : : Good morning.

Sarinata : Have looks please.

Tourist : No thanks.

The data above. The function above in bold word is of the greeting function from seller to tourist. The function of English above greeting expression consist at the setting time, that is, in the morning. The greeting function above is usual expressions because they are uttered with the word "hello" and "good" in their openings.

\subsection{Giving Price}

The expression at the capacity for giving cost is communicated by a seller when her/his is asked by the other person(s) about the cost of the thing(s) which his/her sells. The English term used for the function of giving the cost of things are also very commonly used by the sellers in 
their communications with the tourists. The English expressions that are used by sellers for giving the price can be seen in the followings;
Puspa : Have looks please.
Tourist : What is the price of this necklace?
Puspa : This one is forty thousand rupiah.
Tourist : I love this motif. Maybe I want to see the others.
Puspa : It's okay.
Tourist : Thank you very much.
Puspa : Thank you, Sir.

The short dialogue above is part of the data. The sentence bold is the considered to function in giving the price. The function bold above means the price of a necklace. The price of that necklace is "forty thousand rupiah". "This one is" is telling for kind of necklace and follow tell the price. So, it is the price for one kind of necklace that is forty thousand rupiah. The function above is considered on neutral expression because that can be communicated when the circumstance at whatever point and any individuals.
Puspa : Hallo. Good afternoon.
Tourist : Hallo.
Puspa : : This is good quality.
Tourist : How much?
Puspa : I give you good price. One hundred seventy thousands rupiah.
Tourist : Where could I see the other models?
Puspa : Oya. Follow me to see the other sarong.
Tourist : : I like this one, but I want to see another shop.
Puspa : Okay, thank you.

From the conversation above that is part of data 2 . The bold sentence above is a function to tell the price. The price of thing that the seller tells to the tourist is good price, because the seller above says "I give you good price", but behind of that sentence is also says that price is "one hundred seventy thousands rupiah". This function above is informal expression because that expressed by the seller to tourist to impolite.
Ernawati : Good afternoon.
Tourist : Good afternoon.
Ernawati : Have looks please. Can I help you?
Tourist : Yes. Please, I want to big size
Ernawati : Wait moment please. This is ninety thousand.
Tourist : How much?
Ernawati : Ninety thousand rupiah.(1)
Tourist : Okay. I'll take it too
Ernawati : This one, fifty thousand rupiah(2)
Tourist : How it all?
Ernawati : One hundred fifty thousand rupiah.(3)
Tourist : Okay.

In conversation above, those are four bold sentences is considered to tell the price function. In sentences (1) seller say the price, she says "Ninety thousand rupiah", because tourist asks about the price. Sentences (2) seller tells the price, because tourist takes two shirts. In sentences (3) seller telling the price "One hundred fifty thousand rupiah" because tourist ask about all the price of shirts. 


\subsection{Getting Information}

The information which someone want to get from the others is generally asked by utilizing information starting with the word why, who, where, when, what and other wh-words. The sellers at Campuhan,Ubud also using that expression to getting information from tourists.

Oka : This is eighty thousand rupiah.

Tourist : This color is very pretty. That was my favorite color.

Oka : what do you like a green color or plain?

Tourist : I love both of them.

The bold sentence above is uttered by the seller at Capuhan, Ubud as the function of getting information from their tourist. The data which the merchant needs to get from the vacationer is about the favored tone from green and plain dress, and visitors pick both. The function above is formal expression because the seller used "what" word to asking for getting information.

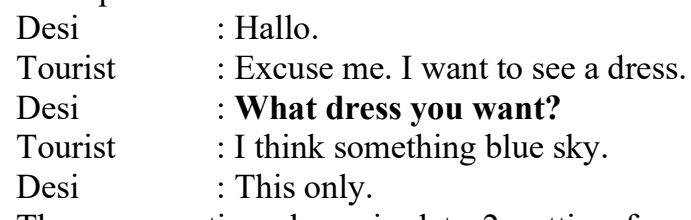

The conversation above is data 2 cutting from conversation 11 . The bold sentence is a function used by seller to get information from tourist. The information above is about asking the color of dress tourist need. "Blue sky" is the color of dress need tourist from the shop. The function above is informal expression because that expression it not following by words "a" and "do" in the middle of sentence.
Tourist : Well I took.
Desi : So, you take two sarongs?
Tourist : Yes, please.

Seen from above is categorized to getting information, function bold that is used by the sellers in getting information from tourist. The information is the tourist takes two sarongs. The seller ask "So, you take two sarongs?" and tourist answer "Yes, please". The function is make sure tourist takes two sarongs. The function of seller above is informal expression because it is not with correct grammar, and the seller didn't used wh-word.
Febra : : This statue is two hundred thousand Rupiah.
Tourist : Could I order a statue like the picture?
Febra $\quad:$ O... yes. You can show the picture please?
Tourist : like this one, how much the price?

The bold sentence from data 4 above is function of getting information. The function above is used when the seller asks about the picture of the statue. The seller wants to know what kind of statue the tourist will want to make. The function above is categorized as an informal expression because seller didn't used wh-word.

\subsection{Inviting Someone}

Inviting is one of the language capacities that are utilized by individuals to invite others. In light of the data information, their also some expressions for inviting the tourist to do something were convey by sellers.
Oka : Can I help you?
Tourist : : I just sight see.
Oka : Come in please, do you like the black shirt?
Tourist : No, I like green or white color. 
Seen from conversation 8 above, the seller says "come in" means that the seller inviting tourist to come in to the shop. And then following with ask sentence "do you like the black shirt?". So the function here is inviting tourist "come in" to choose color of shirt. The function of this conversation is formal expression because the seller used word "please" to inviting tourist.

Tourist : Where could I see the other models?

Puspa : Oya. Follow me to see the other sarong.

The inviting function is telling tourist to following the seller to the see other model of sarongs. The function above is a common expression because it can be expressed when the situation whenever and any people.

Tourist : Hallo. Good afternoon.

Febra : Hallo.

Tourist : Could I see the Buddha statue?

Febra : Yes, of course, Sir. Let us to see it.

The meaning function bold above is asked when seller telling tourist to see the statue. Further, the function above is informal because it is not consist by the word please. This word have to placed at the end of the communication. Since it isn't convey by the word please. This word ought to be set at the end of this expression.

\subsection{Offering Things}

The English speaker who also usually express the offering expressions are the sellers at Campuhan Ubud. They communicate the expressions to the tourists coming to look the store. The sellers commonly express the offering expression after communicate them.

Ernawati : Good afternoon.

Tourist : Good afternoon.

Ernawati : Have looks please. Can I help you?

Tourist : Yes. Please, I want to big size.

The data 1 above is a cutting conversation 4 communicated by the seller at Campuhan Ubud after they talk to the tourist.

The offering function above is considered as neutral expression because it can be communicated when the situation whenever and to any people.

Oka : Come in please, Do you like the black shirt?

Tourist : No, I like green or white color.

The bold sentence above considered on offering things function. The information of the speaker of the function above was offered to the tourist when the seller offered the black shirt. The function above is neutral communication because it use the word 'do' as their opening.
Tourist : I want to try in my body.
Oka : Can I help you with that?
Tourist : Yes, please. It's so hard.

The help of the speaker of the function above was offered to the tourist when, the guest wants to wearing the dress. The offering function above is considered as neutral expression because it can be communicated in situation whenever and to any people.

\section{Oka : Do you want see if I show another dress?}

Tourist : Ya. Of course, May I love it.

The speaker of the function above offered the tourist to show another dress. The function above is common expression because they made the word 'do' as their opening. If the seller used expression of the person (tourist), such as sir or else, is added at the end of expression, is can also considered as polite expressions. 


\section{Thanking}

The expression for thanking is almost convey in any conversation, and also expressed by any people involving in the conversation.

Tourist : Where could I see the other models?

Puspawati : Oya. Follow me to see the other sarong.

Tourist : I like this one, but I want to see another shop.

Puspawati : Okay, thanks.

The sentence a bold above is a part of thanking function, from seller at shop Campuhan , Ubud. The function thank seller is to appreciate the tourist to came to the shop and asking about sarong.
Tourist : I'll be back
Febra : Okay, Sir, How much you want?
Tourist : No, no I'll be back, thank you
Febra : Okay, thank you sir.

The function thanking above expressed sellers, because the tourist already come to the store.

Tourist $\quad$ : Ya... I bought for my son, size small.

Ernawati : Thank you very much.

The data above is a considered in function thanking by seller and tourist. The seller said thanks to the guest after the tourist bought clothes from the store, small sizes for child from the tourist.

Tourist : Okay. I'll take this.

Oka : : It is good for you.

Tourist : Okay, Thank you.

Oka : You're welcome.

The tourist thanking function after seller smoothing and neatly wrapped clothes bought by tourist and sellers says use word "You're welcome" to appreciate the tourist, because they bought some clothes.

\section{Conclusion}

Based on the analysis, researcher concluded that the English functions uttered by sellers, in their communication with their tourists have six functions of language that I can find the sellers at Campuhan Ubud, there are (1) greeting their tourists, (2) telling their tourists about the prices of things, (3) getting information from their tourists, (4) inviting their tourists, (5) offering things to their tourist, and (6) thanking their tourist. These greetings are mostly interpret by sellers in Campuhan, Ubud, Bali. In their conversations with the tourist, more sellers are used informal and neutral expressions. But some of the sellers used usual expressions which appear in their greeting and thanking expressions. Most of them used ungrammatical language to express the communication, but their purpose can be understood by the tourists when they serve the tourists seems friendly. 


\section{References}

[1] J. Keyton, Communication and organizational culture: A key to understanding work experience. Thousand Oaks, CA: Sage, 2011.

[2] G. P. Delahunty and J. Garvey, The English Language from Sound to Sense. The WAC Clearinghouse, Fort Collins, Colorado, 2010.

[3] J. Blundell, J. Higgens, and M. N, Function In English. Oxford: Oxford University Press, 1982.

[4] I. K. S. Lastara and I. M. Winaya, "Language Functions Used by Taxi Drivers in Sanur Beach," urnal Humanis, Fakultas Ilmu Budaya Unud, vol. 20, 2017.

[5] A. A. I. Y. K. Paramita, I. W. Suarnajaya, and I. G. Budasi, "An Analisis of Language Function and Expression Used by Tour Guides at Bali Best Memory Tours in Handling Tourists," Jurnal Pendidikan Bahasa Inggris Undiksha, vol. 5, no. 2, 2017. 